\title{
EUNOMICS:
}

\section{A BEHAVIORAL-SCIENCE VIEW OF THE NATIONAL RAILROAD ADJUSTMENT BOARD SYSTEM*}

\author{
JOSEPH LAZAR †
}

THE National Railroad Adjustment Board copes with the inevitable human frictions and labor conflicts growing out of the administration of the collective bargaining agreements on the nation's railroads. This task of government and of law is performed by representatives of management and of labor. The Board has evolved from a private collectivebargaining committee to the status of a public quasi-judicial agency of the federal government. The legal profession finds the mechanism strange. The agency does not seem to fit conventional legal categories of structure. Nor does the agency seem to function pursuant to traditional legal categories of process. It is not surprising, therefore, that members of the legal profession attempt to modify the Board so that it may be more congruent with their customary image of a judicial institution.

The danger exists that legalistic tinkerings with the mechanism may destroy the Board's capability of coping satisfactorily with the grievances of the industry. Soundly conceived innovations, on the other hand, may strengthen the institution and promote a more adequate solution to the problems before it. The clear and immediate need is for an appropriate application to the Board of what Professor Lon L. Fuller has labelled "eunomics": "the science, theory or study of good order and

* In 1957-58, while a Law and Behavioral Science Senior Research Fellow in The Law School, The University of Chicago, the writer began to explore ideas which have taken form in this paper. He is especially indebted to Dean Edward H. Levi for his encouragement in pursuing the approach reflected in this paper, and to Edward $A$. Shils, Professor of Sociology and Social Thought, The University of Chicago, for his stimulating seminar in law and behavioral science.

$\dagger$ A.B. 1938, J.D. 1940, University of Chicago. Visiting Professor of Business Administration and Industrial Relations, University of Minnesota; member, Illinois and Michigan bars. Author, Readings and Materiais in Business LaW (195I); DUE Process ON THE RAILROADS (rev. ed. I958); [with W. L. McNaughton] INDUSTRIAL RELATIONS AND THE GOVERnMENT (1954); [with C. W. Stimson] RECENT Cases AND Materials in Business LaW (1955). Contributor to legal periodicals. 
workable arrangements." Eunomics would include the non-legal as well as the legal. ${ }^{1}$

Recent developments in the behavioral sciences beam energizing sunlight toward the growth of eunomics. Behavioral science represents the "combined endeavor of many fields investigating all aspects of behavior, leading to understanding of human beings as individuals and in social relations." Significantly, the ordering of human affairs through law is based upon many generations of human experience and understanding of human beings as individuals and in social relations. Law and behavioral science seek for increased understanding of human behavior and for the regularities of lawfulness and orderliness in the universe of human interaction. Eunomics, by bringing together law and behavioral science, may yield insights of practical value for the workings of legal institutions, including the National Railroad Adjustment Board.

The National Railroad Adjustment Board may be seen as possessing the essential properties of behavioral systems ${ }^{3}$ that (I) exist in spacetime, (2) have calculable boundaries that separate systems from their environments, (3) are made up of parts or subsystems, (4) exhibit an interchange of energy or information among their parts or subsystems, (5) have their parts or subsystems associated in functional relationships, and (6) have energy interchange, inputs, and outputs crossing the boundaries between the systems and their environments.

${ }^{1}$ Fuller, American Legal Philosoplyy at Mid-Century, 6 J. LEGAL Ed. 457, 477 (1954). The writer wishes to acknowledge his indebtedness to Professor Fuller for his helpful criticism, comment, and suggestions on an earlier draft of this paper. Although Professor Fuller's concept of eunomics is central to this paper, the treatment of the concept here is the responsibility of the author alone.

${ }^{2}$ Statement on National Support for Behavioral Science, 3 BeHAvioral SCIENCE 218 (1958), subscribed to by Raymond A. Bauer, George P. Berry, Paul H. Buck, Ralph W. Gerard, H. Bently Glass, Rev. C. Lrdlir Glenn, Clyde K. Kluckhohn, Donald G. Marquis, Robert K. Merton, James G. Miller, Max F. Millikan, Frank Stanton, Samuel A. Stouffer, Ralph W. Tyler, and John C. Whitehorn. The scope of behavioral science is described as including "many studies in the fields of anthropology, biochemistry, ecology, economics, genetics, geography, history, linguistics, mathematical statistics, neurology, pharmacology, physiology, political science, psychiatry, psychology, sociology, and zoology." Behavioral science applications are said to ramify into "advertising, business administration, education, government, human engineering, labor relations, law, medicine, military science, operations research, personnel selection, public relations, and many other aspects of human endeavor."

${ }^{3}$ The theory of behavioral systems here described is essentially that presented by Miller, Toward a General Theory for the Behavioral Sciences, ro AM. PsYchologrst 513 (1955). The writer is indebted to Dr. Miller for his criticism and suggestions. Distortions and deviations from the theory, of course, are the responsibility of the writer alone. 
I. The Board exists in space-time

The National Railroad Adjustment Board was established by Congress in the I934 amendments to the Railway Labor Act. ${ }^{4}$ The Board's headquarters are in Chicago, Illinois, and it is in its twenty-sixth year of existence. Accordingly, from a behavioral systems viewpoint, the Board exists in space-time and may be understood as a reality rather than a conceptual system. The Board's existence as a reality system is further shown in what follows herein.

\section{The Board has calculable boundaries}

The 1934 amendments to the Railway Labor Act created the Board with jurisdiction over disputes "growing out of grievances or out of the interpretation or application of agreements concerning rates of pay, rules, or working conditions." ${ }^{\circ}$ The Act also provides that the disputes ${ }^{6}$

shall be handled in the usual manner up to and including the chief operating officer of the carrier designated to handle such disputes; but, failing to reach an adjustment in this manner, the disputes may be referred by petition of the parties or by either party to the appropriate division of the Adjustment Board with a full statement of the facts and all supporting data bearing upon the disputes.

In the handling of grievances from lower to higher levels of management, ordinarily there is only a small percentage of grievance disputes on a carrier which are appealed to the Board. ${ }^{7}$ From a behavioral systems viewpoint, the arrested flow of cases from carrier to Board indicates that there is a calculable boundary between the Board and the carriers.

The Supreme Court of the United States has held that the Board possesses exclusive primary jurisdiction over its grievance disputes. Parties-must ordinarily bring their cases to the Board, and not to the

${ }_{4}^{4} 8$ Stat. 1185 (1934), 45 U.S.C. \$ 151 (1958).

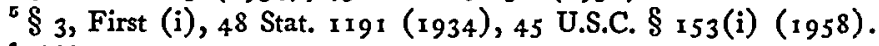

- Ibid.

"In March 1945, although some estimated 10,000 grievance disputes were pending on the nation's individual railroads, more than half were settled without submission. Report of E. J. Connors to President Harry S. Truman on Conditions in the First Division, N.R.A.B. Aug. $3^{1}$, 1945, p. 3 (reproduced by the National Mediation Board for general information, Jan. 21, 1947). Some 2,233 cases were received and docketed by the First Division during fiscal year 1944-45. National Mediation Board ElEventir ANN. REP. 61 (1946). Five hundred and seventy-three cases were received and docketed in fiscal year 1945 46. National Mediation Board Twelffi ANN. REP. 72 (1947). 
courts at the outset. Grievance disputes, accordingly, are ordinarily barred from the courts. From a behavioral systems standpoint, this may be understood as a boundary between the courts and the carriers. The exclusive primary jurisdiction of the Board, however, may be seen as a lesser or more easily passable boundary between the Board and the carriers. $^{8}$

The Board has issued more than 30,000 awards. Very few of these, perhaps not even a hundred, have been appealed from the Board to the courts. This is understandable, in part, because the Railway Labor Act provides that except for money awards, the Board's awards shall be final and binding; ${ }^{9}$ and because the railroad brotherhoods have used economic strength as a sanction for the carriers' compliance with awards. From a behavioral systems viewpoint, there is an arrested flow of cases from Board to court, and the boundary between the Board and the courts, in appeal cases or in enforcement suits, is clear. Whether the boundaries should be strengthened or dissolved in the administration of justice in certain fields-as in the area of racial or minority discrimination-involves policy determination that realistically copes with what may be called "the boundary problem." It should be observed that legalistic terminology pertaining to "jurisdiction," “judicial review," "administrative adjudication," "jurisdictional and constitutional facts," "due process," etc., often involve "the boundary problem." Lawmen, using legalistic terminology, generally follow a logical and systematic symmetry, and sometimes this is to the disadvantage of the actual workings and consequences desired from the legal machinery. Thus, the impact of economic pressures (i.e., the Union's threat to strike a carrier that refuses to put into effect a Board award) must realistically be seen as "establishing "boundaries," even though the "jurisdiction", of a judicial agency is not barred. Conceivably, the legal doctrines themselves may unwittingly constitute fictions that may be corrected through the behavioral systems notion of "boundary." Thus, despite a "boundary" created by economic pressures, the courts, nevertheless, employ the fiction of availability of judicial procedures in enforcement suits to attempt to justify conceptions of due process of law..$^{10}$

\footnotetext{
${ }^{8}$ Slocum v. Delaware, L. \& W. Ry., 339 U.S. 239 (1950); Ordér of Railway Conductors of America v. Southern Ry., 339 U.S. 255 (r950); Order of Conductors v. Pitney, 326 U.S. 56x (1946); Transcontinental \& W. Air, Inc: v. Koppal, 345 U.S. $653(1953)$.

${ }^{0} \S_{3}$, First (m), 48 Stat. II 11 (r934), 45 U.S.C. $\S_{153}(\mathrm{~m})$ (1958).

${ }^{10}$ Washington Terminal Co. v. Boswell, 124 F.2d 235 (D.C. Cir. 194I).
} 
3. The Board System is made up of parts or subsystems

The National Railroad Adjustment Board is divided by the Railway Labor Act into four divisions. ${ }^{11}$ Each division operates and makes its decisions independently and separately of the other divisions. ${ }^{12}$ The Board as a whole functions as a single fiscal unit, and under the Act possesses broad procedural rule-making authority. ${ }^{13}$ This rule-making authority, however, has been largely left for exercise by the separate divisions. Each division has jurisdiction over different classes of railroad employees: Division One has jurisdiction over train and yard service employees, including engineers, firemen, hostlers, outside hostlers, conductors, and trainmen; Division Two has jurisdiction over shopcraft employees; Division Three has jurisdiction over station, tower, and telegraph employees, signalmen, clerks, freight handlers, express, station, and store employees, maintenance-of-way workers, and sleeping-car conductors, porters, maids, and dining-car employees; Division Four has jurisdiction over marine employees and all other employees not included under the first three divisions. Division One of the Board has an input of approximately seventy-five per cent of the disputes submitted to the Board, and for the purposes of this paper, will be regarded as the Board. ${ }^{14}$

From a behavioral-systems viewpoint, Divison One may be described as consisting of parts or subsystems. Thus, the five management and the five labor members may be thought of as comprising two separate subsystems. ${ }^{15}$ The subsystem of five management members may

\footnotetext{
${ }^{11} \S_{3}$, First (h), 48 Stat. 1190 (1934), 45 U.S.C. $\S_{153}$ (h) (1958).

${ }^{13} \mathrm{Ibid}$. "The said Adjustment Board shall be composed of four divisions, whose proceedings shall be independent of onc another . ..."

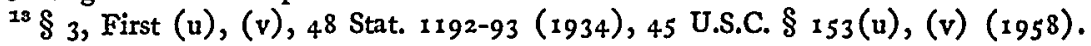

14 "It will be noted that of the $42,06 \mathrm{I}$ cases docketed by the Board since it began operation, 32,107 have been docketed by the first division. Thus, for the 20-year period during which the National Railroad Adjustment Board has been in operation, the first division has accounted for 74 percent of all cases docketed." 20 NATIONAL Mediation Board ANn. ReP. 55 (1955).

${ }^{16}$ Both the carriers and the railroad brotherhoods, under the Railway Labor Act, $\S 3$, First (b) and (c), exercise appointive powers over the inembership of the Board, who serve without tenure and on good behavior. Thus, there is effective a suprasystem consisting of management membership on the Board together with the railroads' controlling organization, and, similarly there is a comparable suprasystem for labor membership. The properties of the management suprasystem and of the labor suprasystem quite likely bear significantly upon the functioning of the Board system and its subsystems. Because of the intrinsically delicate nature of the relationships and properties of these suprasystems, the instant paper can only notc the possible significance of such suprasystems without detailed analysis at this time.
} 
be viewed as made up of three distinct parts: two members representing the eastern railroads; two members representing the western railroads; and one member representing the southeastern railroads. In comparable fashion, the subsystem of five labor members may be viewed as made up of five parts: one member representing the Brotherhood of Locomotive Engineers; one member representing the Brotherhood of Locomotive Firemen and Enginemen; one member representing the Brotherhood of Railroad Trainmen; one member representing the Order of Railway Conductors and Brakemen; and one member representing the Switchmen's Union of North America.

It is the customary procedure of the Board for its management members and for its labor members to vote as separate blocs in the making of awards on grievance disputes. It is possible, therefore, for any single member of either subsystem to force a deadlock. In the event of a deadlock, an additional subsystem of the Board may be considered as coming into play-the subsystem of the Referee. The subsystem of the Referee is established with the ad hoc selection of a disinterested, neutral individual. The Referee has only one vote in the making of an award, and it is necessary for at least one of the blocs to vote with him in order to break a deadlock. Although the Board has the power under the Railway Labor Act to select a Referee of its own choosing, it has been the experience of the past for the Board, generally, to leave the selection of the Referee to an outside agency, the National Mediation Board.

Under the Railway Labor Act, from a legal point of view, there appears to be a Board that is bipartisan, consisting of ten individual members, or of eleven individual members in event of deadlock; but from a behavioral-systems viewpoint, the Board consists of two subsystems, or of three subsystems in the event of deadlock. From a legal standpoint of interpretation and application of collective bargaining agreements, one might anticipate the identical result whether the claimant be a union member or not; but from a behavioral-systems viewpoint, the fact of union membership or not might be decisive in the functioning of the subsystems. A behavioral-systems approach will search for those factors that govern subsystem performance, even though such factors may not appear relevant in the making of legal determinations on the interpretation and application of the terms of collective bargaining agreements. 
4. There is an energy (or information) interchange among the parts or subsystems of the Board

Board awards are reached in executive session. Prior to the rendering of awards, the members of the Board engage in considerable preliminary discussion. Thus, a case involving a western railroad may call for a conference between the management members representing the western railroads; and after some agreement is reached between these members, further meetings may be held with the other management representatives. In conjunction with the holding of such caucuses, there may be any number of telephone conversations, luncheon chats, memoranda, and other communications involved in the working out of a consensus. Similarly, the labor members of the Board may engage in a considerable number of conversations, telephone calls, writings, meetings, etc. in connection with their working out their stand on some case or issue. In addition, one or more members of the management bloc might discuss matters with one or more members of the labor bloc. Occasionally, in certain categories of grievance disputes wherein slight involvement is present for all members of the Board, there may be tacit understanding that agreements reached between particular management members and particular labor members will be adopted by the Board in the rendering of awards in executive session. In cases involving a Referee, the writings and presentations of the members to him are more formal and are generally limited to the official presentations in executive session.

From a behavioral-systems viewpoint, the numerous communications constitute informational or energy interchange among the parts or subsystems of the Board system. Under the Railway Labor Act, it is contemplated that the bipartisan makeup of the Board will produce awards resulting from a number of interchanges between the management and labor groups. It is assumed that the Board mechanism will produce awards resulting from such interchange, regardless of the classification of grievance dispute being determined. Such assumptions, however, may prove to be unrealistic in certain categories of cases. Thus, from a behavioral-systems standpoint, it is conceivable that of the total number of awards rendered by the Board currently with the aid of the Referee (over eighty per cent), there may be slight or perfunctory informational interchange between the management and labor subsystems prior to deadlock, or that there may be an insignificant and minimal interchange in certain categories of cases. Accordingly, from a behavioral-systems 
standpoint, in certain categories of cases, there may be so few interchanges between the subsystems of management and labor, and so very many interchanges with the subsystem of the Referee, as to suggest that the bipartisan Board in such categories of cases has ceased functioning as a system and that, instead, there exists, realistically, a nonpartisan Board, with the Referee as the single decision-maker. If it should be determined as a matter of fact that this last statement is substantially valid in such categories of cases as discipline or seniority. rights or related areas, the Railway Labor Act might well be amended to bring about a more appropriate nonpartisan agency of justice. A behavioral-systems approach might illuminate the actualities of the functioning of the Board so that misconceptions of fact may be discarded. The task of eunomics in determining "good order" and "workable arrangements" may be facilitated, accordingly, through the application of behavioral-systems concepts.

\section{The parts or subsystems of the Board are associated in functional relationships}

The task of the Board is to process its docket of incoming grievance disputes and to issue awards on these cases. The management and labor members of the Board most closely connected with the parties in a particular dispute have the primary responsibility of studying the case and making recommendations to their colleagues in the management or labor blocs. Thus, the management representative of the eastern railroads with prior experience with $X$ eastern railroad will familiarize himself with the docket of the case involving this railroad, and then he will discuss it with his fellow representative of the eastern railroads. If the case involves the Brotherhood of Railroad Trainmen and the Brotherhood of Locomotive Engineers, the labor members representative of these two organizations will study the case and consider it among themselves. If the labor members decide that the claim has no merit and should be denied, or if the management members decide that the claim is meritorious and should be sustained, they will so recommend to their fellow management and labor members. If both groups accept the recommendations, then, if the recommendations are the same, the entire Board membership in executive session will issue an award in the case; or if the recommendations are incompatible, will deadlock the case. If the case is deadlocked, the Referee will consider the case with the Board, and ordinarily the Referee's choice of the winning side in the dispute will move the adoption of the award; but if both labor and 
management groups are dissatisfied with the Referee's proposed award, the Referee will modify his proposal so that at least one of the groups will vote for its adoption.

From a behavioral-science-systems viewpoint, the Board system's functioning in the transformation of input grievance to output award depends on the effective performance of the parts or subsystems in their functional relationships. Thus, inability of the two eastern management representative members to agree amongst themselves, or failure of the two western management representatives, or failure of the interested labor representatives to reach agreement will result in a deadlocked case requiring Referee determination. Failure of the management bloc to agree, or failure of the labor bloc to agree will also result in the need for a Referee decision. A behavioral-systems approach will focus on those factors that may be responsible for disagreement within the parts or subsystems of the Board. It is not unlikely that such an approach may promote the utilization of the Railway Labor Act provision that: ${ }^{16}$

Any division of the Adjustment Board shall have authority to empower two or more of its members to conduct hearings and make findings upon disputes, when properly submitted, at any place designated by the division: Provided, however, that final awards as to any such dispute must be made by the entire division as hereinafter provided.

It would seem that efficient functioning of the parts or subsystems of the Board is a necessary condition for the use of the panel provision of the Railway Labor Act, and that the Act contemplates or takes for granted that there will obtain such an efficient functioning of the parts or subsystems of the Board. It is significant that despite a considerable backlog of cases amounting to several years' accumulation, the panel provision of the Act has not been employed. Accordingly, it would seem that the practical and common sense of the legislator and lawyer must search out the factors that interfere with the effective functioning of the agency established by law. The behavioral-systems approach that directs attention to the parts or subsystems of the Board in their functional relationships may be suggestive in furthering the "good order and workable arrangements" called for by eunomics.

6. There is an energy interchange, inputs, and outputs that cross the boundaries of the Board system and its environment

The Board is several years behind in its work. The task of reducing

${ }^{10} \S_{3}$, First (k), 48 Stat. 1191 (1934), 45 U.S.C. ${ }_{153}$ (k) (1958). 
the backlog and becoming current in its work must, of course, take into consideration not only the matter of efficient Board operation, but also the number and status of grievance dispositions on the nation's railroads. Thus, it is apparent that if a large number of particular railroad companies are unable to dispose of their grievances, there may be such a large number of grievance appeals to the Board as to increase its backlog. In 1949, the backlog assumed the proportions of a five-year delay, with over 4,000 cases awaiting disposition. It was found that sixteen railroads, with one-third of all employees involved, accounted for seventyfive per cent of the Board's total awards, and that the western railroads, with only thirty per cent of the train, engine, and yard service employees, were submitting to the Board thirty-three per cent more grievances than the rest of the railroads combined. To deal with the backlog in I949, the Board, by resolution, established two supplemental boardsone to deal with conductors' grievances, and one to deal with firemenengineers' grievances. ${ }^{17}$ In 1953 , the supplemental boards were terminated, although the backlog was approximately 2,800 cases. $^{18}$

From a behavioral-systems point of view, the Board is not isolated from its environment, and if the Board is to function as a system, there must be some balance between inputs (grievances) to the Board and outputs (awards) to the environmental railroad systems. The Board, accordingly, together with its environment, may be said to constitute a "suprasystem" with a tendency to maintain "equilibrium." This equi-

${ }^{17}$ Two supplemental boards—one dealing with conductor-trainmen's grievances, and one dealing with fireman-engineers' grievances-were established in May 1949. The Board resolution providing for these supplemental boards expressly provided: "Cases where the interest of an organization not represented on such supplemental Board is asserted by either party or by a member of the First Division, shall be retained by the First Division and shall not be assigned to such supplemental Board." 16 NATIONAL MEDiATION BOARD ANN. REP. 90 (1950).

${ }^{18}$ The supplemental boards were terminated on March 23, 1953. The backlog of pending cases had been reduced to 2,825 not only as a result of the supplemental boards, but largely due to the establishment of special system boards of adjustment on individual railroads. Thus, there were fewer submissions to the Board and increased withdrawal of submissions. "The reduction in submissions and increase in withdrawals were primarily responsible for reducing the backlog of pending cases from 4, I86 to 2,825 ..." 19 National MEdiation BoARd ANN. REP. 68 (1953). Adequate analysis of the subject of investigation herein calls for detailed study of the differences between the railroad systems at opposite ends of the scale in their capacities to cope with the strains evidenced by grievances. The task of developing a useful scale appears to be feasible within a behavioral-systems theoretical framework and may emerge from the studies being undertaken.

${ }^{10}$ Related to the notion of equilibrium is the concept of "homeostasis." Alfred E. Emerson develops the notion of "dynamic" homeostasis in his thought provoking paper, 
librium is disturbed if there is a lack or excess of inputs or outputs. According to behavioral-systems notions, "strain" results when the equilibrium is disturbed, and there is a range of stability for variables within systems within which the system may be able to absorb or to make correction for strains; but beyond the point of correction or range of stability, the system under strain collapses. Further, according to the theory, feedback mechanisms contribute to the steady state of the system by distributing and transmitting energy and information, and strains are thereby reduced. If the system is to maintain its steady state, however, it must have some form of reciprocal relationship with its environment in regard to inputs and outputs.

Conventionally, from the standpoint of the legislator or legal scholar, the task of establishing and improving agencies of law and government is a function of the State. Accordingly, the practitioners in the law crafts are inclined to make their diagnoses, sharpen up their instruments of legal surgery, and operate through the powers of the State. A behavioral-systems approach, however, recognizes the interdependence, unity, and reciprocal relationships of the Board system and its environment. Thus, when it is appreciated that the backlog problem of I949 was corrected without legislative assistance, but through activities of the railroads and labor organizations, the Board and its environmental suprasystem, it would appear to be sound policy to build a legislative or judicial attitude conducive to the strengthening and health of the suprasystem. It might be noted that the "suprasystem" has actually coped with the backlog problem in at least three ways: (I) the establishment of the supplemental boards, (2) the establishment of a number of special adjustment boards, and (3) the employment of international representatives of the railroad brotherhoods to confer with particular railroad managements in disposing of troublesome grievance dockets.

Ordinarily, the legal craftsman will focus on the legal dispute and the legal machinery for coping with the dispute. Those conditions that give rise to the disputes are often felt to be outside the province of the legal profession, as constituting the subject-matter of economics, sociology, psychology, etc. The discipline of eunomics, however, when employing behavioral-system concepts, will not reject the need for concern with the nonlegal factors involved in the rise of the legal problem.

Dynamic Homeostasis: A Unifying Principle in Organic, Social, and Ethical Evolution, The Scientific Monthly, Feb. 1954, p. 67. Emerson credits both Walter Cannon and Ralph W. Gerard with contributing to the concepts of physiological and social homeostasis. 
Thus, from a behavioral-systems viewpoint, grievance disputes may be seen to be an outgrowth of technological changes in the railroad industry that are accompanied by collective-bargaining agreements antedating the technological changes. Accordingly, it would be improper to condemn or to dismantle the Board for rendering awards consistent with possibly inappropriate collective-bargaining agreements. Instead, support should be given towards establishing those factors that are conducive towards modernizing the agreements in keeping with the advancing technology and competitive role of the railroad industry.

The environmental strains, of course, have their impact on the Board system, and the need is to reduce these strains in the suprasystem. Where, in particular cases, there may be financial strains on a railroad company due to insufficient income (lack of inputs) or due to large expenditures (excess of outputs), it may be expected that the management may attempt to reduce the strain by reducing costs and finding new income sources; for unless the necessary correction can be made, the boundaries of the system cannot be maintained and the system is subject to termination (by abandonment, sale of assets, merger, consolidation).$^{20}$ Economy measures by the railroad frequently reduce the income of the employees and result in employee strain. Grievances flow, as a consequence, and find their way to the Board. The grievances, of course, may be representative of fundamental economic problems confronting the railroad industry, and the solution to the grievance situation may lie, intrinsically, in a sound national transportation policy. Accordingly, a behavioral-systems approach, by focusing on inputs and outputs crossing the boundaries of the systems and their environments, leads to a recognition of the suprasystem as a matter for attention. This is to say, the railroad industry as a whole must be considered if the Board is to be treated.

\footnotetext{
${ }^{20}$ Parsons \& SMelser, Economy and Society 295 (1956), suggests that "economic theory is a special case of the general theory of social systems, which is in turn one of the main branches of the developing general theory of action." Although the term "system" as used by them is not the same as in the behavioral theory sense of Miller, it is not unlikely that the larger general theory of social systems being developed by Parsons may supply a framework for the demarcation of meaningful units of society for study within a behavioral-systems orientation.
} 